\title{
Tests of steel arch and rock bolt support resistance to static and dynamic loading induced by suspended monorail transportation
}

https://doi.org/10.2478/sgem-2019-0009

received February 22, 2019; accepted May 9, 2019.

\begin{abstract}
At present, the suspended monorail systems constitute a very common means of transportation in the Polish hard coal mines. The main advantages of the suspended monorail include the independence of the route from the working floor surface irregularities and the possibility to transport cargo of significant mass and size.

The masses and dimensions of machines and devices transported via monorail have increased considerably in recent times. This particularly concerns the transport of longwall system elements. In Poland, the maximum speed of suspended monorail travel is $2 \mathrm{~m} / \mathrm{s}$. Due to the fact that preparations are currently underway to increase the maximum speed above $2 \mathrm{~m} / \mathrm{s}$, it is necessary to inspect what influence it will have on work safety and mining support stability.
\end{abstract}

Current operational experience and tests have shown that dynamic loads induced by the suspended monorail transportation have a significant influence on the roadway support stability, working protection durability and on the monorail operators. This is particularly true during the emergency braking of a suspended monorail by means of a braking trolley, where the overloads reach $3 \mathrm{~g}$.

Bench tests of the selected steel arch and rock bolt support elements utilised in the Polish hard coal mines were conducted in order to determine the resistance of steel arch and rock bolt supports to static and dynamic loads.

The article presents the results of the tests conducted on a steel arch support in the form of the sliding joints of an $€ \mathrm{P} / \mathrm{V} 29$ yielding roadway support, which is commonly employed in the Polish hard coal mines. Tests of elements of the threaded bolts with trapezoidal threads over the entire rod length were conducted as well.

*Corresponding author: Andrzej Pytlik, Central Mining Institute, Katowice, Poland, E-mail: apytlik@gig.eu;ja.pytlik@gmail.com
The conducted strength tests of steel arch and rock bolt support elements under static and dynamic loading have shown that dynamic loading has decisive influence on the support's retaining of its stability. Support element stability decreases along with the increase of the impact velocity. This concerns both the steel arch support and the rock bolt support.

Keywords: Mine transport; suspended monorail; transport-induced static and dynamic support loading; steel arch and rock bolt support resistance.

\section{Introduction}

At present, suspended monorail systems constitute a very common means of transportation in the Polish hard coal mines..$^{[1,2]}$ The main advantages of the suspended monorail include the independence of the route from the working floor surface irregularities and the possibility to transport cargo of significant mass and size.

The masses and dimensions of machines and devices transported via monorail have increased considerably in recent times. This is particularly related to the transport of longwall system elements and road support elements. For the most part, the mass of the transported cargo loads the frame of the ŁP support, and in some cases, also the rock bolts that are used as support reinforcement elements. Fig. 1 presents an example view of a route of a suspended monorail with a transport of steel arches that load the $Ł P$ yielding steel arch support frame. ${ }^{[3]}$

Fig. 2 presents the mine working diagram with suspended monorail. The dynamic influence of the vibrating transported cargo on the support elements is particularly visible during the sudden braking of the monorail. Experience shows that the vibrations of the transported cargo occur not only in the travel direction of the monorail, which results primarily in deformations of the monorail route, ${ }^{[4]}$ but also in the direction of gravity. 


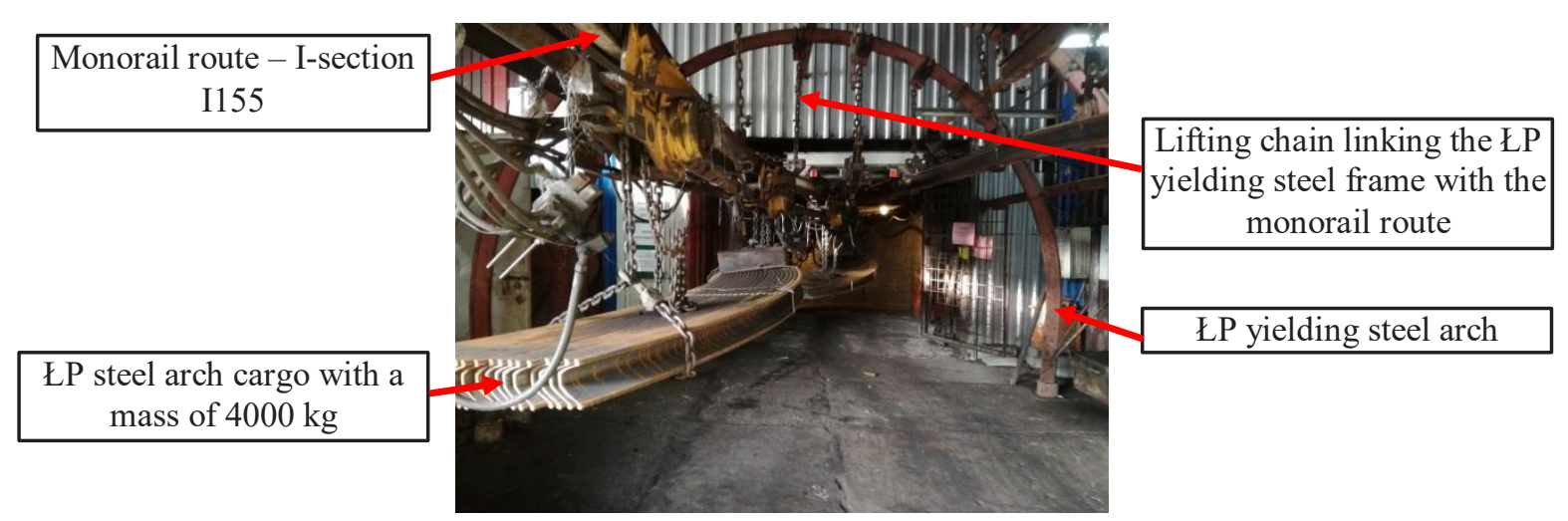

Figure 1: Example view of a route of a suspended monorail with a transport of steel arches that load the $Ł P$ yielding steel arch support frame.

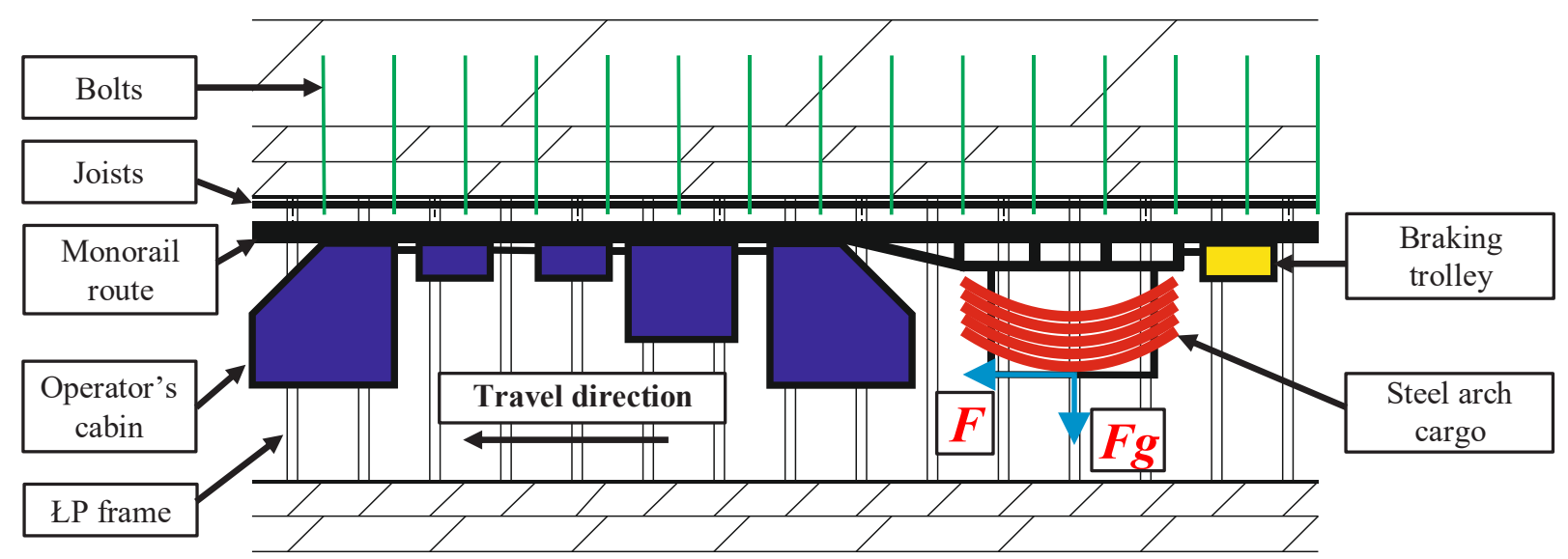

Figure 2: Mine working diagram with transportation via suspended monorail.

The influence of loads on the support in the direction of gravity may affect the support elements in various ways, such as: support frame camber beam deformation, ${ }^{[5]}$ significant yields in the joints, as well as the tension, bending and shearing of the rock bolts reinforcing the ŁP support camber beams. This is why the article focuses on the analysis of the operational characteristics of the support frame sliding joint and the yielding bolts subjected to static and dynamic loads, in order to present the various influence that loading may have on the support. Fig. 3 presents an example diagram of the loading of a sliding joint of an $€ P$ yielding support frame reinforced by means of rock bolts via short joists with a force $F$ that results in its yield.

In Poland, the maximum speed of suspended monorail travel is $2 \mathrm{~m} / \mathrm{s}$. Due to the fact that preparations are currently underway to increase the maximum speed above $2 \mathrm{~m} / \mathrm{s}$, it is necessary to inspect what influence it will have on work safety and mining support stability.
Current operational experience and tests have shown that dynamic loads induced by suspended monorail transportation have a significant influence on the roadway support stability and working protection durability and on the monorail operators. ${ }^{[4,5]}$ This is particularly true during the emergency braking of a suspended monorail by means of a braking trolley, where the overloads reach $3 \mathrm{~g}$.

Bench tests of selected steel arch and rock bolt support elements utilised in the Polish hard coal mines were conducted in order to determine the resistance of steel arch and rock bolt supports to static and dynamic loads.

The article presents the results of tests conducted on a steel arch support in the form of the sliding joints ${ }^{[6,7,8]}$ of an $Ł P / V 29$ (ŁP-type yielding steel arch support frame constructed from a V29 section), which is commonly employed in the Polish hard coal mines. Tests of elements of threaded bolts with trapezoidal threads over the entire rod length were conducted as well. The tests were conducted under static and dynamic loading. 


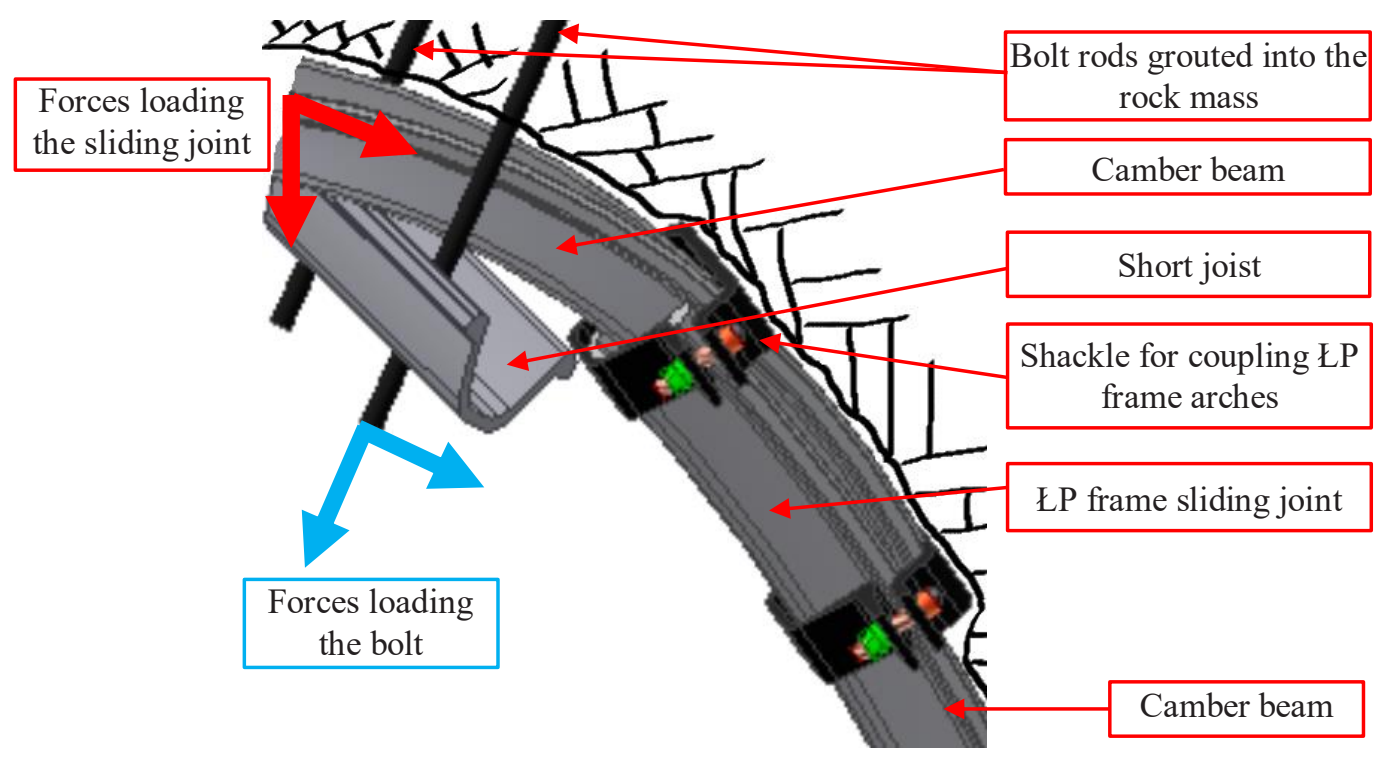

Figure 3: Loading diagram of the $Ł P$ yielding support frame joint and bolts.

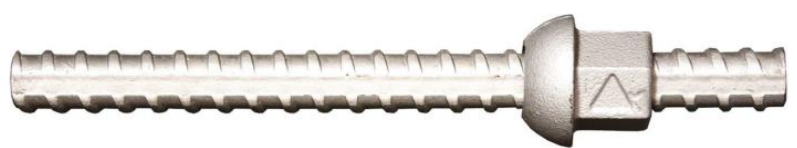

(a)
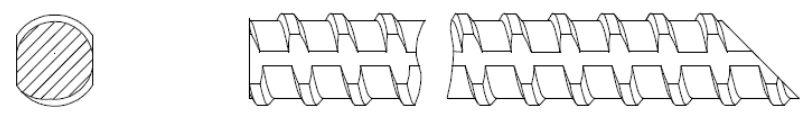

(b)

Figure 4: Bolt rod and nut: (a) - view of the rod with the nut; (b) drawing of the rod with a trapezoidal thread and sectional view.

Instrumentation of an existing GIG drop hammer (test method with the free fall of mass) facility for steel arch and rock bolt support tests ${ }^{[9,10,1]}$ was carried out as well, together with the development of a methodology enabling the testing of bolt rods under dynamic bending and shearing loads.

\section{Bench Test Methodology and Results}

\subsection{Bolt rod tensile strength under static load}

Bolt rod tests were conducted according to the applicable Polish standards ${ }^{[12,13]}$ in a tensile testing machine with digital force and displacement registration. The tests under static load were carried out using a ZD100Pu-type static testing machine. The force measurements were carried out via a strain gauge force sensor (accuracy class 0.5 ), while displacement measurements were carried out via a potentiometric sensor (accuracy class 1). The measuring sensors were connected to a measuring amplifier (accuracy class 0.03) coupled to a computer. The measurement data was recorded on the computer with a sampling frequency $f_{\mathrm{s}}=10 \mathrm{~Hz}$.

The following elements of the bolt (Fig. 4) were tested: - bolt rod with a trapezoidal thread (13 $\mathrm{mm}$ thread pitch) over the entire $2 \mathrm{~m}$ length, $21.3 \div 21.8 \mathrm{~mm}$ minor diameter and $25.1 \mathrm{~mm}$ maximum trapezoidal thread outer diameter,

- $50 \mathrm{~mm}$ tall nut (13 $\mathrm{mm}$ thread pitch).

The result of the bolt rod test under static tensile loading is presented in Fig. 5.

The length of the studied bolt rod during testing was approx. $2000 \mathrm{~mm}$. The maximum force registered during the test was $F_{\text {smax }}=271 \mathrm{kN}$, while the rupture occurred at an elongation of $L=112 \mathrm{~mm}$.

In order to determine the load capacity of the rod-andnut assembly, tests were conducted according to Fig. 6 .

Results of the three rod-and-nut assembly load capacity tests are presented in Fig. 7 and Table 1. 


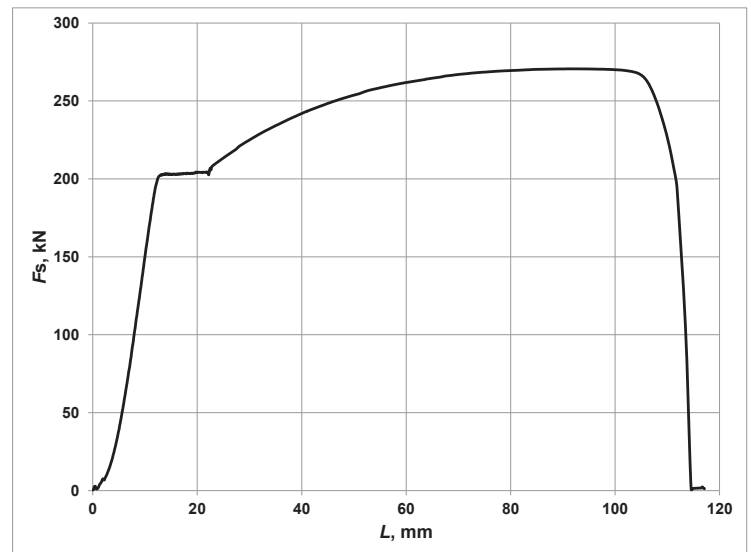

(a)

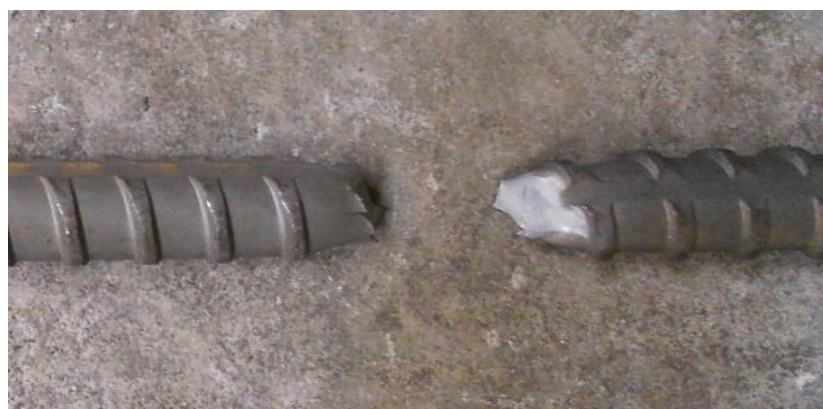

(b)

Figure 5: Bolt rod test under static tensile loading: (a) - loading course as a function of bolt rod elongation; (b) - ruptured rod after the test.

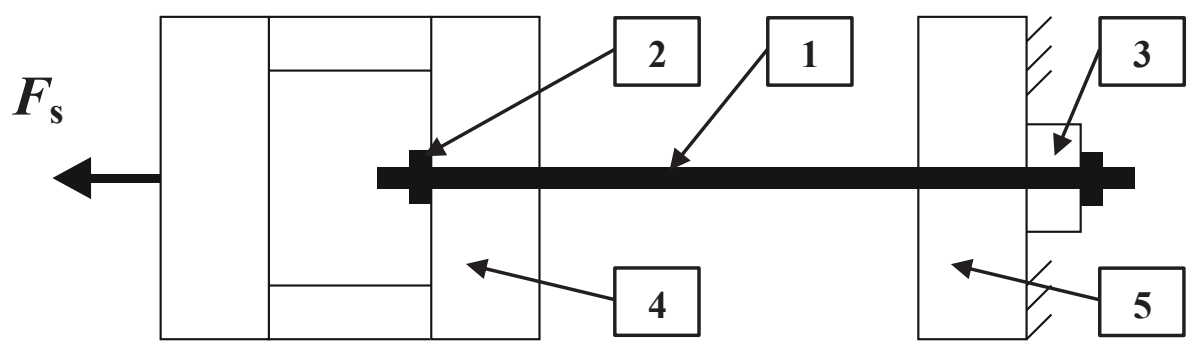

$1-$ bolt rod

2 - nut

3 - strain gauge force sensor

4 - tensile testing machine mobile element

5 - tensile testing machine immobile element

Figure 6: Test stand diagram for bolt tests under static load.

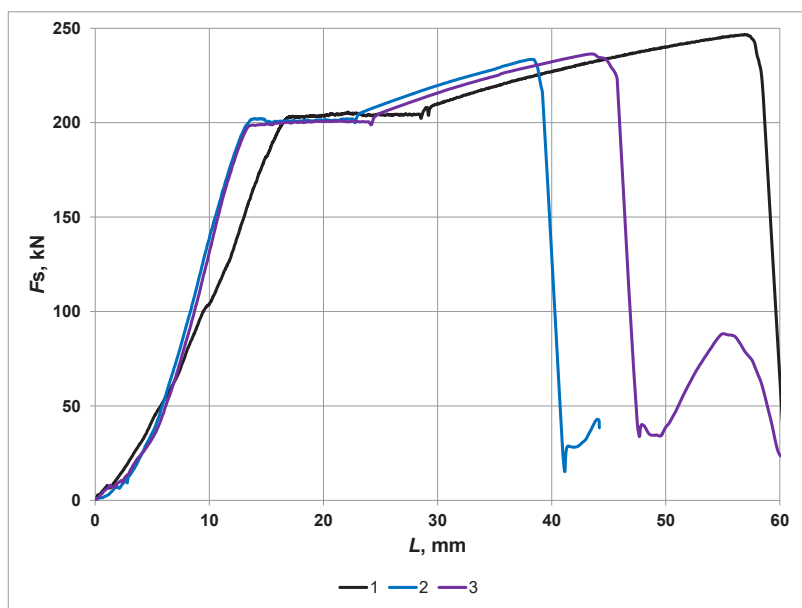

Figure 7: Courses of load as a function of elongation under static load.
Table 1: Results of the rod-and-nut assembly load capacity tests.

\begin{tabular}{llll}
\hline $\begin{array}{l}\text { Test } \\
\text { number }\end{array}$ & $\begin{array}{l}\text { Maximum load } \\
\text { value } F S_{\max }, \mathbf{k N}\end{array}$ & $\begin{array}{l}\text { Bolt elongation } f \\
\text { corresponding to } \\
L_{\text {max, }} \text { mm }\end{array}$ & $\begin{array}{l}\text { Post-test } \\
\text { inspection }\end{array}$ \\
\hline 1 & 247 & 56.9 & $\begin{array}{l}\text { Bolt nut } \\
\text { thread shearing }\end{array}$ \\
2 & 234 & 38.1 & \\
3 & 236 & 43.3 & \\
\hline
\end{tabular}

Nut thread shearing was observed during the tests, which was the main cause of bolt load capacity loss. At the same time, it was determined that the bolt rod thread exhibited slight superficial marks after the test, generated as a result of the shearing. This suggests that it may be possible to obtain greater bolt-and-nut assembly load capacity by using nuts with better mechanical properties 


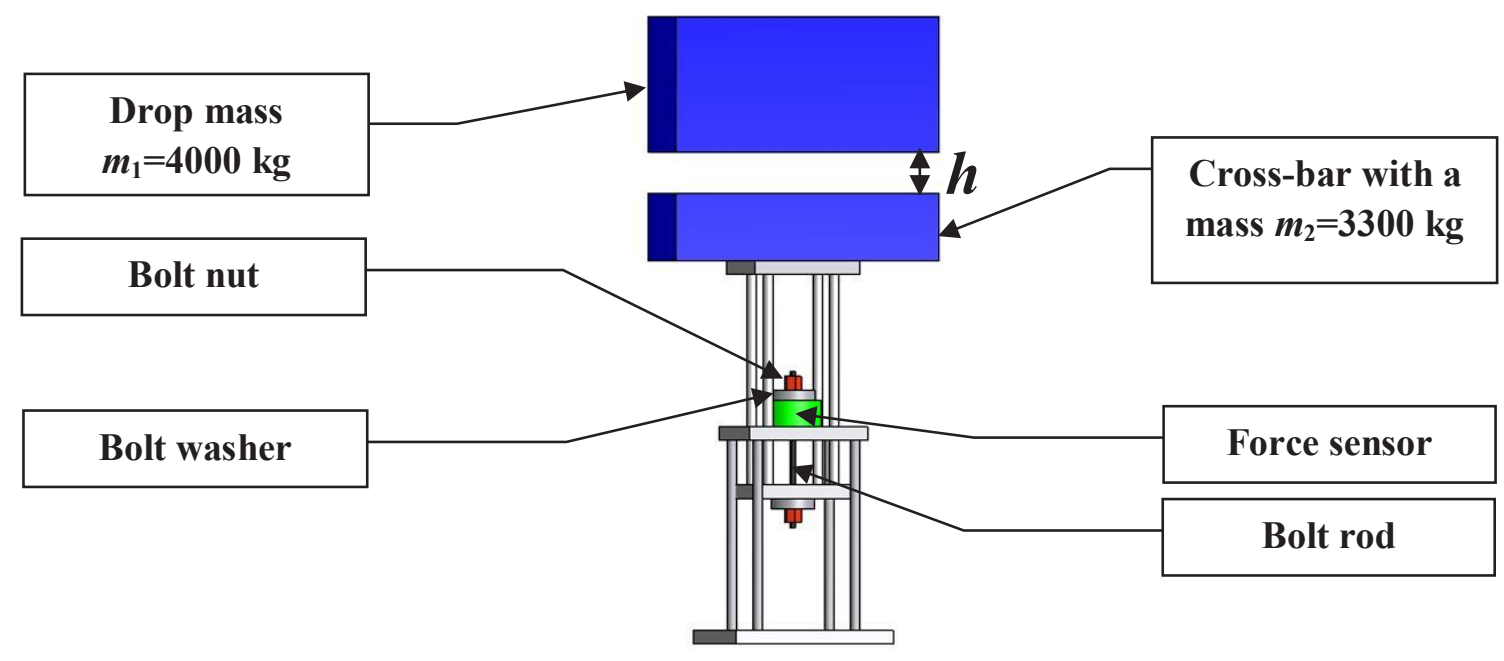

Figure 8: Test facility diagram.

and by fitting the rod-and-thread nut contact areas better (the rod coarse thread was produced by rolling).

\subsection{Bolt rod tensile strength under dynamic load}

The bolt tests were conducted at a drop hammer test facility, depicted as a diagram in Fig. 8.

The principle of the bolt tensile strength tests under dynamic loading is the free fall of the mass $m_{1}=4000 \mathrm{~kg}$ onto the cross-bar with a mass $m_{2}=3300 \mathrm{~kg}$ (statically loading the tested bolt) from a height $h$.

The bolt impact velocity $v$ during the test is calculated from the following formula:

$$
v=\sqrt{2 \mathrm{gh}}, \mathrm{m} / \mathrm{s}
$$

where: $\mathrm{g}$ - gravitational acceleration $9.81 \mathrm{~m} / \mathrm{s}^{2}$.

During bolt tests under tensile impact loads, the bolt dynamic resistance force $F_{\mathrm{d}}$ and rod elongation $L$ are registered with a sampling frequency $f_{\mathrm{s}}=9600 \mathrm{~Hz}$. The maximum value $F_{\text {dmax }}$ of the bolt dynamic resistance force $F_{\mathrm{d}}$ at a given impact velocity $v$ is determined during the test.

Each tested bolt is subjected to a series of dynamic loads, starting from a drop height $h=1 \mathrm{~cm}$; then $h=2 \mathrm{~cm}$, and so on, until its failure.

The bolt test results are presented in Fig. 9 and in Table 2.

A chart depicting the relation of the maximum force $F_{\text {dmax }}$ as a function of impact velocity $v$ is presented in Fig. 10.

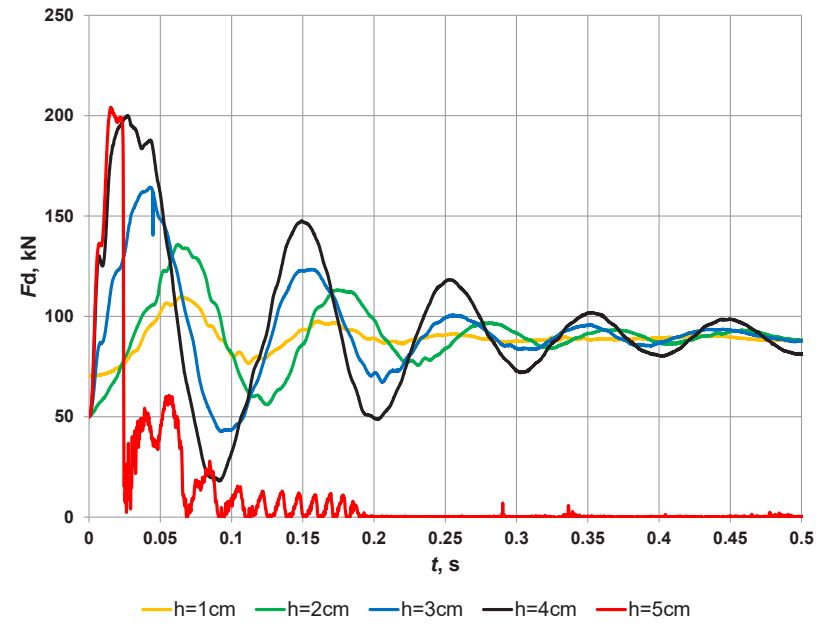

Figure 9: Courses of load as a function of time under dynamic tensile loading of the bolt rods.

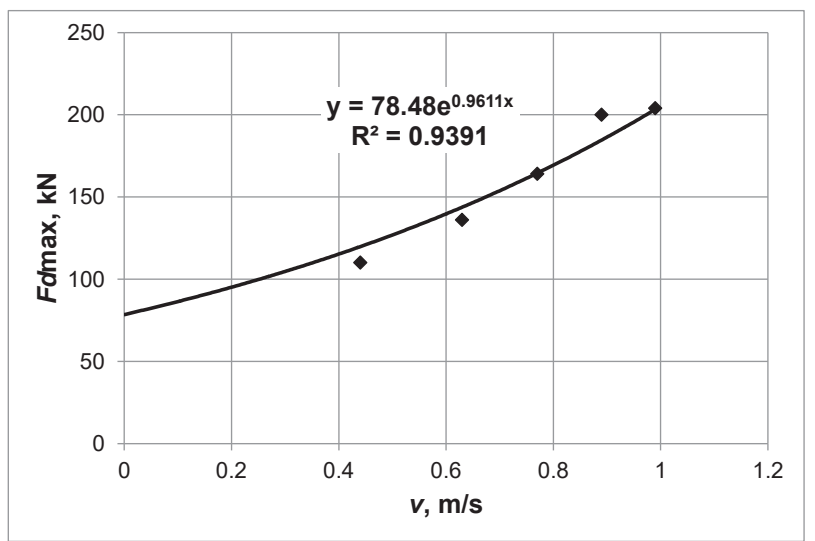

Figure 10: Relation of the maximum force as a function of impact velocity. 
Table 2: The result of the bolt rod test under dynamic tensile loading.

\begin{tabular}{|c|c|c|c|c|c|c|}
\hline $\begin{array}{l}\text { Test } \\
\text { number }\end{array}$ & $\begin{array}{l}\text { Drop } \\
\text { mass } \\
m_{1}, \mathrm{~kg}\end{array}$ & $\begin{array}{l}\text { Cross-bar } \\
\text { mass } \\
m_{2}, \mathrm{~kg}\end{array}$ & Drop height $h, \mathbf{m}$ & $\begin{array}{l}\text { Impact } \\
\text { velocity } v \text {, } \\
\mathrm{m} / \mathrm{s}\end{array}$ & $\begin{array}{l}\text { Maximum load } \\
\text { value } F_{\text {dmax, }} \text { kN }\end{array}$ & $\begin{array}{l}\text { Post-test } \\
\text { inspection }\end{array}$ \\
\hline 1 & 4000 & 3300 & 0.01 & 0.44 & 110 & \multirow{4}{*}{$\begin{array}{l}\text { The rod and nut were not } \\
\text { destroyed }\end{array}$} \\
\hline 2 & & & 0.02 & 0.63 & 136 & \\
\hline 3 & & & 0.03 & 0.77 & 164 & \\
\hline 4 & & & 0.04 & 0.89 & 200 & \\
\hline 5 & & & 0.05 & 0.99 & 204 & $\begin{array}{l}\text { Bolt nut thread shearing } \\
\text { and cracking }\end{array}$ \\
\hline
\end{tabular}

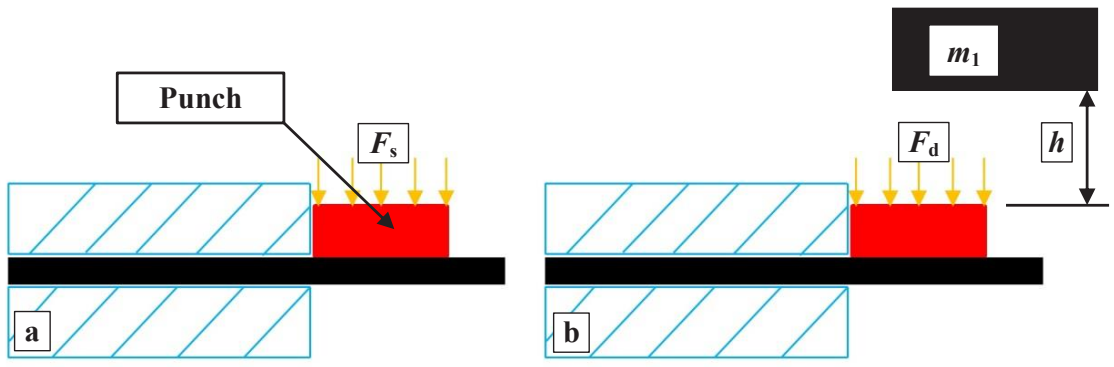

Figure 11: Diagram of the test stand for bolt rod shear tests under: (a) - static load; (b) - dynamic load.

Failure of the bolt nut as a result of the dynamic force's shearing of the thread occurred at Fdmax $=204 \mathrm{kN}$ and impact velocity $v=1 \mathrm{~m} / \mathrm{s}$. Thread wear marks on the inside of the nut indicate an uneven distribution of the thread loading, which is typical for this kind of threaded bolt with a rolled thread not covering the entire rod circumference. The results indicate a 16\% decrease in bolt strength parameters under dynamic loading (average load capacity is $200 \mathrm{kN}$ ) compared to static load (average load capacity is $239 \mathrm{kN}$ ).

\subsection{Bolt rod shear strength under static and dynamic load}

Bolt rod shear tests under static and dynamic loads were conducted at a test stand presented as a diagram in Fig. 11. The tests used the same shearing instrument, which was in accordance with the applicable Polish standard. ${ }^{[13]}$ The bolt samples for shear tests were $250 \mathrm{~mm}$ long. The shear load was exerted on the segment of the bolt by means of a punch with a diameter of $75 \mathrm{~mm}$.

The principle of the bolt shear strength test under dynamic loading is the free fall of the mass $m_{1}=2500 \mathrm{~kg}$ directly onto the bolt rod from a height $h$.

The bolt impact velocity $v$ during the test is calculated from the formula (1).

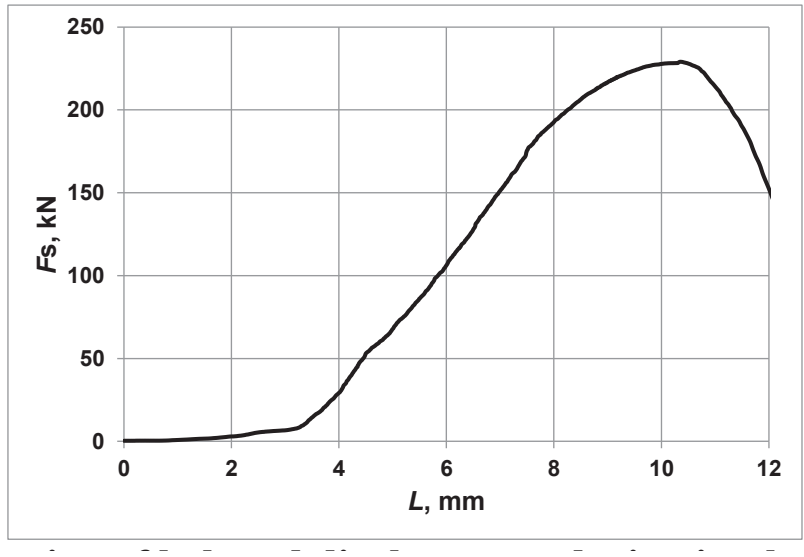

Figure 12: Relation of load as a function of bolt rod displacement during its shearing (maximum shearing force $\mathrm{F}_{\text {smax }}=229 \mathrm{kN}$ ).

During bolt tests under shear impact loads, the bolt dynamic resistance force $F_{\mathrm{d}}$ and phenomenon time $t$ are registered with a sampling frequency $f s=19200 \mathrm{~Hz}$. The maximum value $F_{\text {dmax }}$ of the bolt dynamic resistance force $F_{\mathrm{d}}$ at a given impact velocity $v$ is determined during the test. The result of the bolt rod test under static shear loading is presented in Fig. 12.

The average maximum shearing force obtained during the shear tests under static load was $F_{\text {asmax }}=225 \mathrm{kN}$. 
Table 3: The result of the bolt rod test under dynamic shear loading.

\begin{tabular}{|c|c|c|c|c|c|c|}
\hline $\begin{array}{l}\text { Test } \\
\text { number }\end{array}$ & $\begin{array}{l}\text { Drop } \\
\text { mass } \\
m_{1}, \mathrm{~kg}\end{array}$ & $\begin{array}{l}\text { Cross-bar } \\
\text { mass } \\
m_{2}, \mathrm{~kg}\end{array}$ & Drop height $h, \mathrm{~m}$ & $\begin{array}{l}\text { Impact velo- } \\
\text { city } v, \mathrm{~m} / \mathrm{s}\end{array}$ & $\begin{array}{l}\text { Maximum load } \\
\text { value } F_{\text {dmax, }} \text { kN }\end{array}$ & $\begin{array}{l}\text { Post-test } \\
\text { inspection }\end{array}$ \\
\hline 1 & 2500 & 0 & 0.07 & 1.17 & 194 & the rod was not shorn \\
\hline 2 & & & 0.08 & 1.25 & 213 & the rod was shorn \\
\hline 3 & & & 0.09 & 1.33 & 227 & \\
\hline 4 & & & 0.1 & 1.40 & 228 & \\
\hline 5 & & & 0.12 & 1.53 & 229 & \\
\hline
\end{tabular}

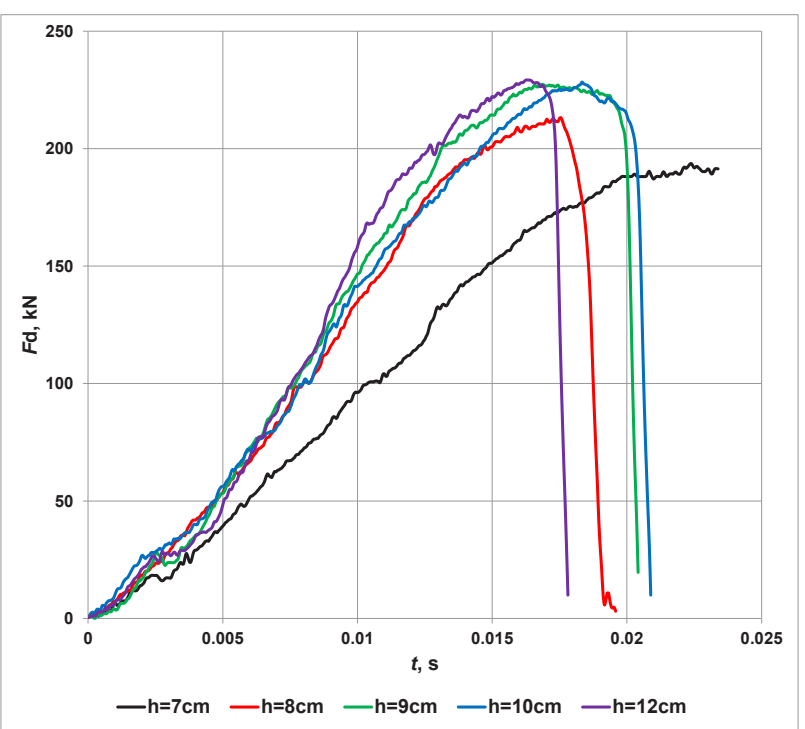

Figure 13: Relations of load as a function of time under dynamic shear loading of the bolt rods.

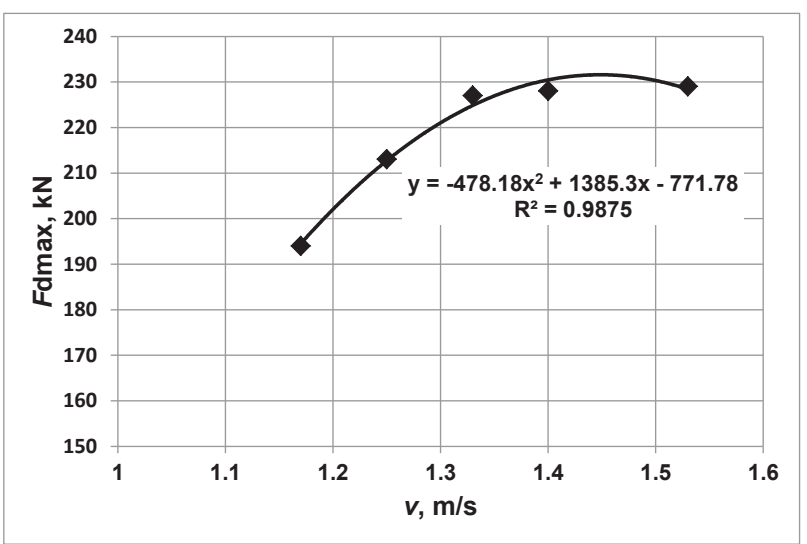

Figure 14: Relation of the maximum shearing force and impact velocity.

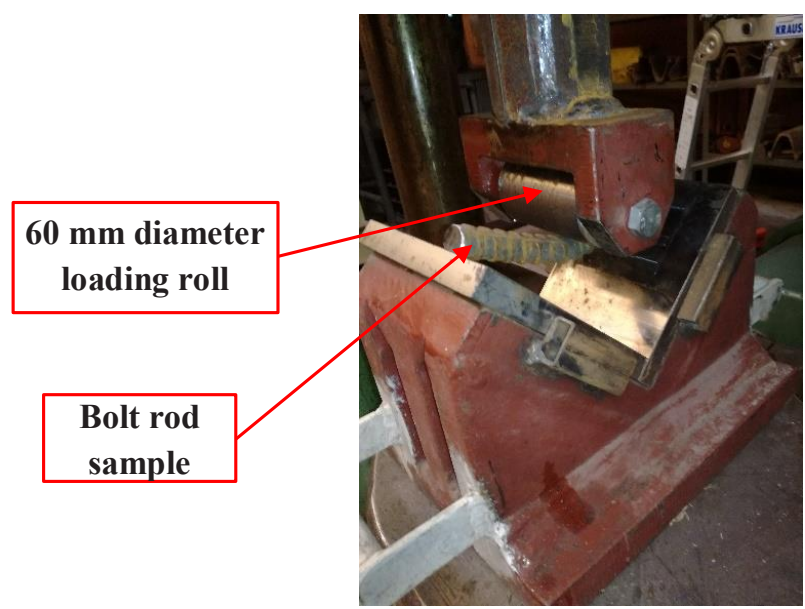

Figure 15: Test stand for bolt rod bending strength tests under static load.

The result of the bolt rod test under dynamic shear loading is presented in Fig. 13, while a result compilation is presented in Table 3. They are comparable with the average bolt rod static shearing force.

A chart depicting the relation of the maximum force $F_{\text {dmax }}$ as a function of impact velocity $v$ is presented in Fig. 14.

The rod was not shorn at impact velocities up to $v=$ $1.17 \mathrm{~m} / \mathrm{s}$, while the maximum force amounted to $F_{\mathrm{dmax}}=194$ $\mathrm{kN}$. Rod shearing occurred at impact velocity $v=1.25 \mathrm{~m} / \mathrm{s}$, while maximum shearing force amounted to $213 \mathrm{kN}$. The force increased slightly at higher impact velocities until it reached approximately $230 \mathrm{kN}$.

\subsection{Bolt rod bending strength under static and dynamic load}

Bolt rod bending strength tests under static load were conducted in a test stand presented in Fig. 15, while the stand for tests under dynamic load is presented in Fig. 16. 


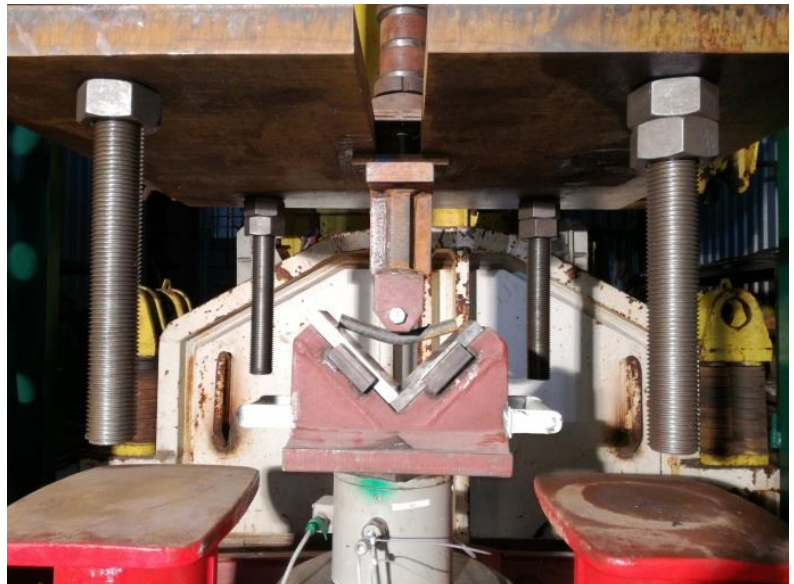

(a)

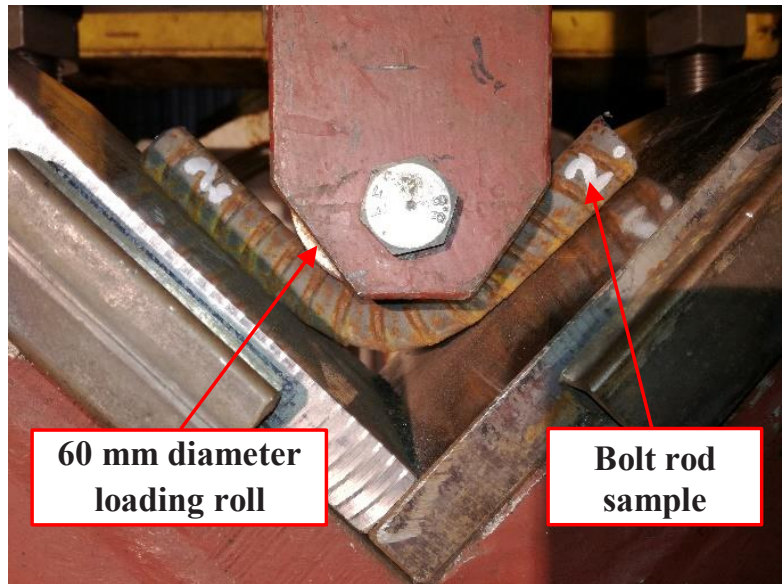

(b)

Figure 16: Test stand for bending strength tests under dynamic load: (a) - rod bending by an angle smaller than $90^{\circ}$; (b) - rod bending by $90^{\circ}$.

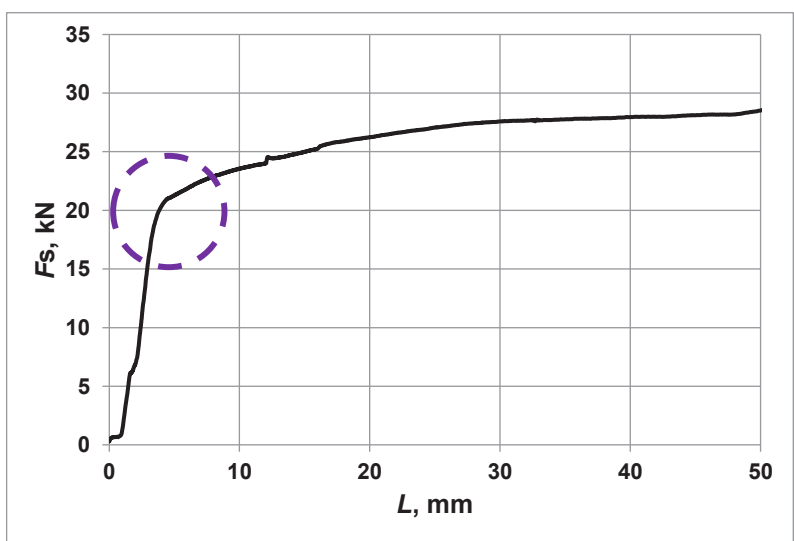

Figure 17: Course of load as a function of bolt rod displacement during its bending (maximum bending force $F_{\text {smax }}=26.3 \mathrm{kN}$ ).

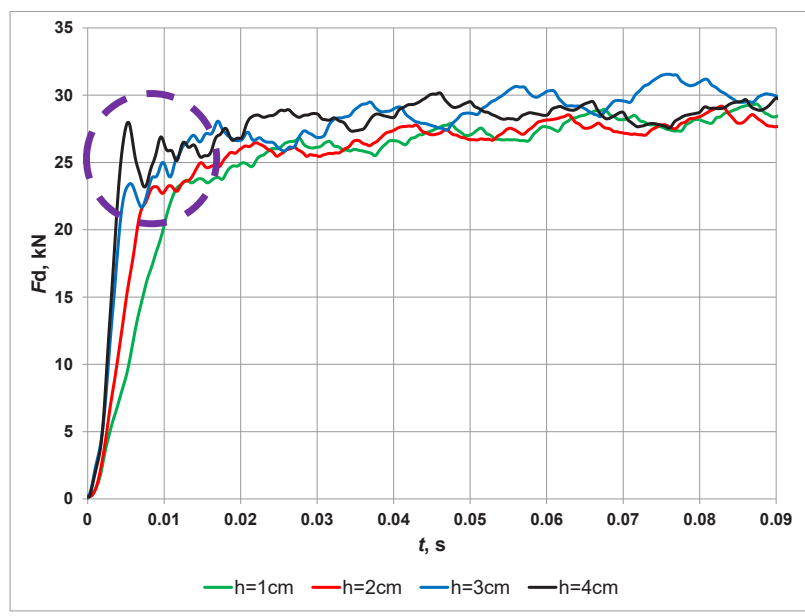

Figure 18: Courses of load $F_{d}$ as a function of time $t$ under dynamic bending loading of the bolt rods.
The tests used the same bending instrument. A $200 \mathrm{~mm}$ long bolt rod sample is propped in the testing device on the surfaces of the device, which produce an angle of $90^{\circ}$. Static and dynamic load is applied to the bolt until the rod bends by $90^{\circ}$. The main objective of the tests was to inspect whether the steel bar used to form the bolt rods would rupture.

The principle of the bolt bending strength test under dynamic load is the free fall of the mass $m_{1}=2500 \mathrm{~kg}$ directly onto the bolt rod from a height $h$.

The bolt impact velocity $v$ during the test is calculated from the formula (1). The load is applied by a $60 \mathrm{~mm}$ diameter roll.

During bolt tests under bending impact loads, the bolt dynamic resistance force $F_{\mathrm{d}}$ and phenomenon time $t$ are registered with a sampling frequency $f_{\mathrm{s}}=4800 \mathrm{~Hz}$. The maximum value $F_{\mathrm{dmax}}$ of the bolt dynamic resistance force $F_{\mathrm{d}}$ at a given impact velocity $v$ is determined during the test.

The result of the bolt rod bending test under static load, with bending by $90^{\circ}$, is presented in Fig. 17 .

The average maximum bending force obtained during the bending tests under static load was $F_{\text {asmax }}=28.1 \mathrm{kN}$.

The result of the bolt rod test under dynamic bending loading is presented in Fig. 18, while a result compilation is presented in Table 4. They are comparable with the average bolt rod static bending force. The differences occur only in the first peak for the dynamic load, the value of which is greater than the load corresponding to the yield stress at static load. 
Table 4: The result of the bolt rod test under dynamic bending loading.

\begin{tabular}{|c|c|c|c|c|c|c|}
\hline $\begin{array}{l}\text { Test } \\
\text { number }\end{array}$ & $\begin{array}{l}\text { Drop } \\
\text { mass } \\
m_{1}, \mathrm{~kg} \\
\end{array}$ & $\begin{array}{l}\text { Cross-bar } \\
\text { mass } \\
m_{2}, \mathrm{~kg}\end{array}$ & Drop height $h, \mathbf{m}$ & $\begin{array}{l}\text { Impact velocity } \\
v, \mathrm{~m} / \mathrm{s}\end{array}$ & $\begin{array}{l}\text { Maximum load } \\
\text { value } F_{\mathrm{dmax},} \text { kN }\end{array}$ & $\begin{array}{l}\text { Post-test } \\
\text { inspection }\end{array}$ \\
\hline 1 & 2500 & 0 & 0.01 & 0.44 & 29.7 & $\begin{array}{l}\text { The rod was not bent by } 90^{\circ} \\
\text { The sample did not rupture }\end{array}$ \\
\hline 2 & & & 0.02 & 0.63 & 29.4 & \multirow{3}{*}{$\begin{array}{l}\text { The rod was bent by } 90^{\circ} \\
\text { The samples did not rupture }\end{array}$} \\
\hline 3 & & & 0.03 & 0.77 & 32.1 & \\
\hline 4 & & & 0.04 & 0.89 & 30.2 & \\
\hline
\end{tabular}
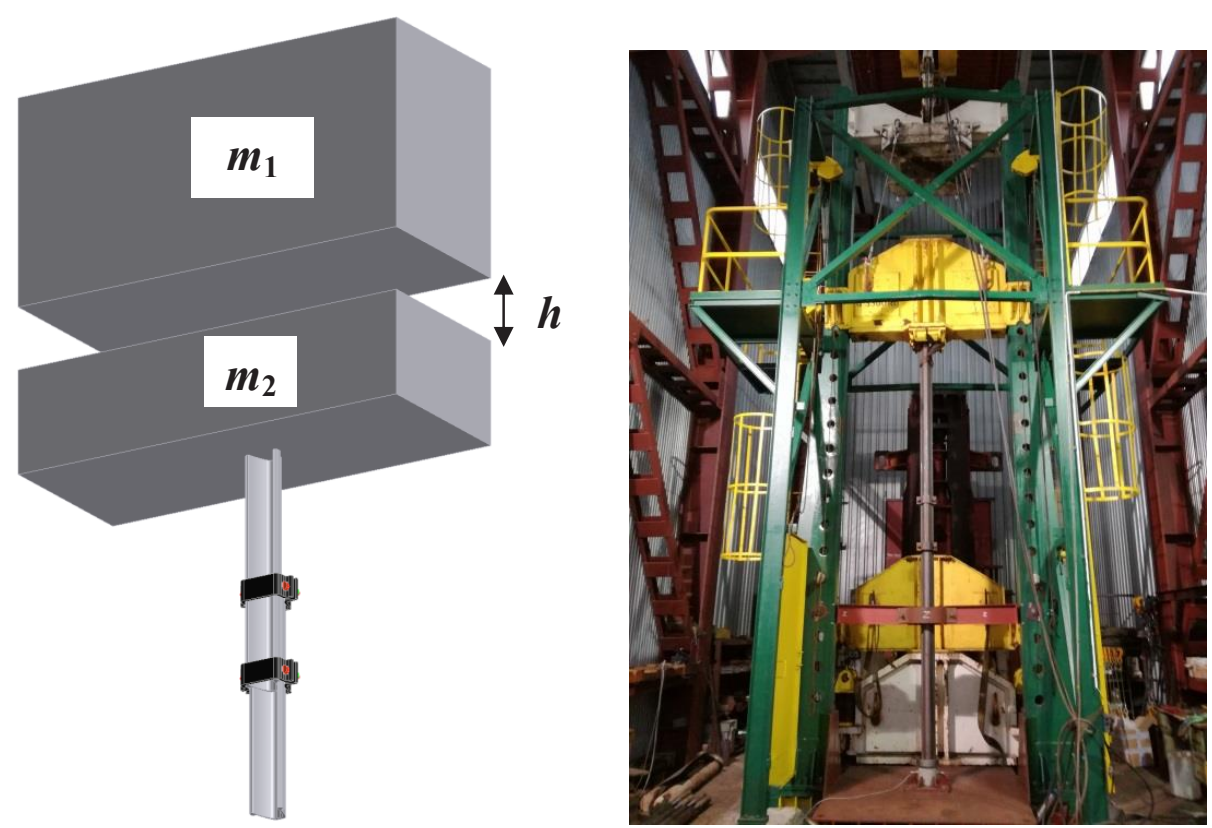

Figure 19: Diagram (left) and view (right) of the facility for sliding joint tests under dynamic load.

\section{5 tPV29 support frame sliding joint load capacity under static and dynamic load}

V29 sliding joint static load capacity tests were conducted according to the applicable standard ${ }^{[14]}$ in a tensile testing machine for static testing where loading is applied by means of a hydraulic actuator. The strain gauge force sensor (accuracy class 1) and potentiometric displacement sensor (accuracy class 1) were connected to a measuring amplifier (accuracy class 0.03 ) coupled to a computer. The measurement data was recorded on the computer with a sampling frequency $f_{\mathrm{s}}=5 \mathrm{~Hz}$.

The principle of the V29 sliding joint dynamic resistance test is the free fall of the drop mass (ram) $m_{1}=$ $4000 \mathrm{~kg}$ from a height $h$ onto a cross-bar with a mass $m_{2}=$ $3300 \mathrm{~kg}$, which applies static load to the joint mounted in the test facility. The height $h$ was progressively increased until the total sliding joint yield was achieved. Fig. 19 presents a sliding joint constructed from two segments of a V29 section, coupled in an approx. $0.6 \mathrm{~m}$ long overlap by means of two SD029-type shackles (the tightening torque of the shackle screws was $\left.M_{\mathrm{d}}=350 \mathrm{Nm}\right)$. The total height of the coupled V29 sections was $4.8 \mathrm{~m}$.

The test result for the joint constructed from V29 sections under static load is presented in Fig. 20.

After the first force peak of $213 \mathrm{kN}$, a systematic decrease in load capacity to approximately $160 \mathrm{kN}$ occurs, which is an adverse effect signifying the loosening of shackle screws.

A similar effect occurs during testing under dynamic load. Results of the tests of joints constructed from V29 sections are presented in Fig. 21, while a result compilation is presented in Table 5 . 


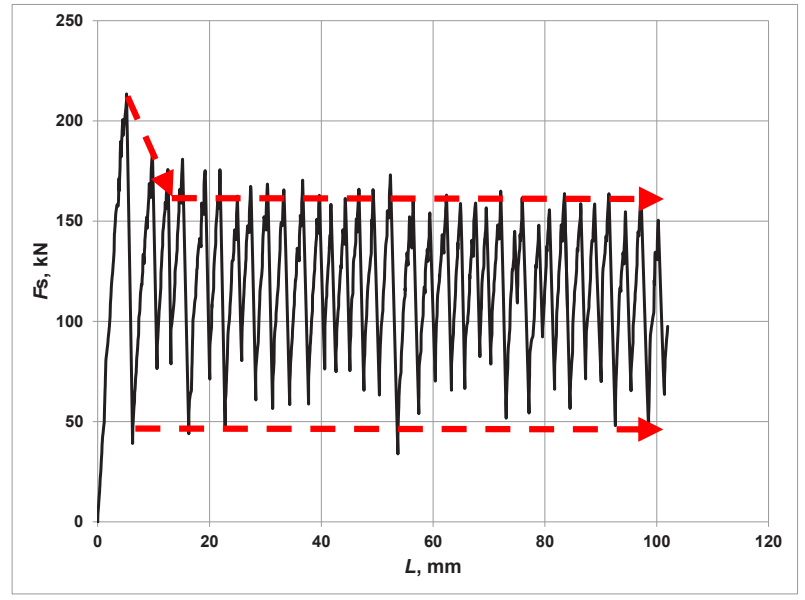

Figure 20: Course of load as a function of joint displacement under static load (maximum loading force $F_{\text {smax }}=213 \mathrm{kN}$ ).
The maximum impact velocity that does not produce total yield should not exceed $v=1.4 \mathrm{~m} / \mathrm{s}$. This is confirmed by the course depicted in Fig. 21(a), where the dotted lines indicate the tendency of the force $F_{\mathrm{d}}$ that is subjected to damping. Greater impact velocities depicted in Fig. 21(b) result in total joint yield, caused primarily by the loosening of the shackle screws. Joint load capacity, visible in the form of high peaks (Fig. 21(b)), often decreases to approximately $100 \mathrm{kN}$, while at times it can decrease to nearly zero, which is a result of the loss of contact between the prop and the cross-bar and ram that exert load upon it.

In the case of an impact mass $m=m_{1}+m_{2}=7700 \mathrm{~kg}$ acting dynamically upon the sliding joint formed of a V29 section with two shackles, at velocities $v \geq 2.8 \mathrm{~m} / \mathrm{s}$ (course in Fig. 19(b) and Fig. 21(b), the sliding joint is not able to stop the momentum of the impact mass.
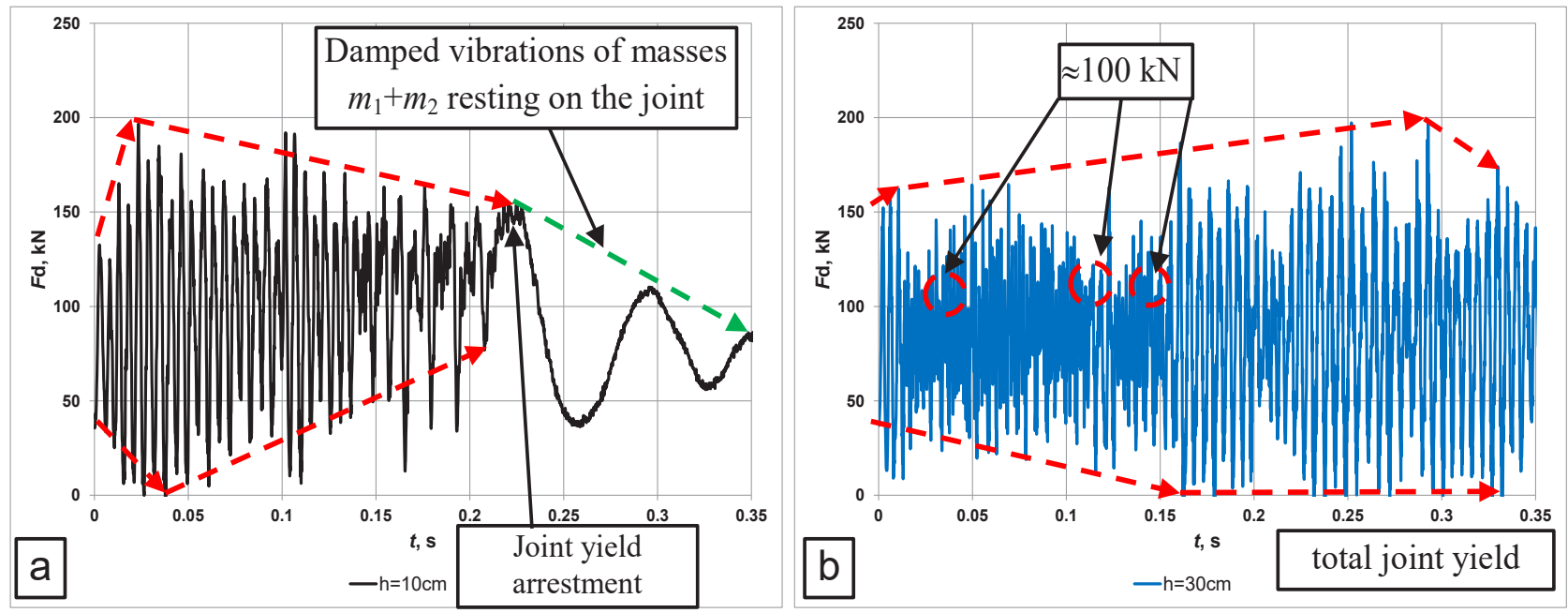

Figure 21: Course of load $F_{\mathrm{d}}$ as a function of time $t$ under dynamic load of the joint at heights: $h=10 \mathrm{~cm} \mathrm{(a)} \mathrm{and} h=30 \mathrm{~cm}$ (b).

Table 5: The test result for the joint constructed from V29 sections under dynamic load.

\begin{tabular}{|c|c|c|c|c|c|c|c|}
\hline $\begin{array}{l}\text { Test } \\
\text { number }\end{array}$ & $\begin{array}{l}\text { Drop } \\
\text { height } \\
h, \mathbf{m}\end{array}$ & $\begin{array}{l}\text { Impact } \\
\text { velocity } \\
v, \mathrm{~m} / \mathrm{s}\end{array}$ & Section & $\begin{array}{l}\text { Number of } \\
\text { shackles }\end{array}$ & $\begin{array}{l}\text { Nut tightening } \\
\text { torque, } \\
\mathrm{Nm}\end{array}$ & $\begin{array}{l}\text { Maximum load } \\
\text { capacity } \\
F_{\text {dmax }}, \mathrm{kN}\end{array}$ & Comments \\
\hline 1 & 0.1 & 1.4 & V29 & 2 & 350 & 197 & $\begin{array}{l}\text { the joint stopped after } \\
\text { approx. } 10 \mathrm{~cm}\end{array}$ \\
\hline 2 & 0.2 & 2.8 & & & & 206 & total joint yield \\
\hline 3 & 0.3 & 4.2 & & & & 197 & \\
\hline
\end{tabular}




\section{Summary}

The conducted resistance tests of steel arch and rock bolt support elements under static and dynamic load have shown that dynamic load has decisive influence on the support's retaining of its stability. Support element stability decreases along with the increase of the impact velocity. This concerns both the steel arch support and the rock bolt support.

The results of rock bolt tests under dynamic tensile loading with an impact velocity $v=1 \mathrm{~m} / \mathrm{s}$ demonstrate a decrease of the strength parameters of the bolts by $16 \%$ in relation to static loading.

At impact velocities of up to $v=1.17 \mathrm{~m} / \mathrm{s}$, the bolt $\operatorname{rod}$ was not shorn. The shearing of the rod occurred only at an impact velocity $v=1.25 \mathrm{~m} / \mathrm{s}$, while the maximum shearing force was $213 \mathrm{kN}$. At greater impact velocities, the force increased slightly until it reached a value $F_{\mathrm{dmax}}=229 \mathrm{kN}$, which was equal to the maximum force $F_{\text {smax }}$ obtained under static loading.

The results of bolt rod tests under dynamic bending loads were comparable to the average static bending force exerted on the bolt rods. Differences occurred only at the first peak during dynamic loading, the value of which was greater than the load corresponding to the yield point under static loading. None of the bolt rod samples ruptured during testing.

The tests of a sliding joint under dynamic loading demonstrated that the beginning of the yield occurred at a force lower than that required under static loading. The maximum impact velocity not resulting in total yield should not exceed $v=1.4 \mathrm{~m} / \mathrm{s}$. Impact velocities $v \geq 2.8$ $\mathrm{m} / \mathrm{s}$ lead to total joint yield, resulting primarily from the loosening of the shackle screw nuts. Such a state can lead to a loss of support stability and result in the caving of a mine working as well as a major accident during transport via suspended monorail.

In order to guarantee safety during suspended monorail travel at speeds exceeding the currently permitted $V_{\max }=2 \mathrm{~m} / \mathrm{s}$, it is recommended to carry out a selection of a support by a scientific research body, which will select the support and prepare an optimal technical solution for the intended maximum travel speed.

Further, resistance tests of steel arch and rock bolt support elements to static and dynamic loads are planned for the future, in order to determine their operational characteristics at various load rates.

Acknowledgements: The article was written as part of the work carried out under the European project INESI Increase efficiency and safety improvement in underground mining transportation routes (Contract ID 754169), financed by the Research Fund for Coal and Steel.

\section{References}

[1] Pieczora E., Suffner H. (2017). Rozwój napędów dołowych kolejek podwieszonych [Development of drives for underground suspended monorails]. Maszyny Górnicze no. 3/ 2017. Instytut Techniki Górniczej KOMAG, Gliwice, 44-57 (in Polish).

[2] Pieczora E., Tokarczyk J. (2017). Rozwój transportu podziemnego wykorzystujacego kolejki podwieszone [Development of mine underground transportation with use of suspended monorails]. Mining - Informatics, Automation and Electrical Engineering. Akademia Górniczo - Hutnicza im. Stanisława Staszica w Krakowie, No. 4 (532) 2017, 107-117 (in Polish).

[3] Polski Komitet Normalizacyjny (2018). Polska Norma: Obudowa wyrobisk górniczych. Odrzwia podatne z ksztattowników korytkowych. Wymagania wytrzymatościowe i badania [Polish Standard: Mine working support. Yielding frames constructed from channel sections. Strength requirements and testing]. PN-G-15022:2018-11. Warszawa (in Polish).

[4] Pytlik, A., Rotkegel, M., Szot, Ł. (2016). Badania wptywu prędkości kolejek podwieszonych na sity w wybranych elementach trasy [The research on the impact of velocity of suspended monorails on forces in selected elements of a track]. Przegląd Górniczy, 72(11), 30-37 (in Polish).

[5] Tokarczyk J., Kania J. (2016). Układy i trasy transportu kolejkami podwieszonymi z napędem własnym do przewozu ludzi $w$ wyrobiskach poziomych oraz pochytych o nachyleniu do $45^{\circ}$ [Systems and tracks of self-powered suspended monorails for transportation of people in horizontal workings and workings with inclination up to $45^{\circ}$ ]. Mining - Informatics, Automation and Electrical Engineering. Akademia Górniczo - Hutnicza im. Stanisława Staszica w Krakowie, No. 3(527), 83-91 (in Polish).

[6] Brodny, J. (2012). Identyfikacja parametrów pracy złącza ciernego stosowanego w górniczej obudowie podatnej wyrobisk korytarzowych [Work parameter identification of sliding joints utilised in yielding gallery working support systems]. Wydawnictwo Politechniki Śląskiej, Gliwice (in Polish).

[7] Brodny, J. (2013). Analysis of operation of arch frictional joint loaded with the impact of freely falling mass. Studia Geotechnica et Mechanica, 35(1), 59-71.

[8] Horyl, P., Šňupárek, R., Maršálek, P., Pacześniowski, K. (2017). Simulation of laboratory tests of steel arch support. Archives of Mining Sciences, 62(1), 163-176.

[9] Pytlik, A. (2015). Process characteristics of hydraulic legs equipped with safety valves at dynamic load caused by a mining tremor. Archives of Mining Sciences, 60(2), 595-612.

[10] Pytlik, A., Prusek, S., Masny, W. (2016). Methodology for laboratory testing of rockbolts used in underground mines under dynamic loading conditions. SAIMM Journal of The Southern African Institute of Mining and Metallurgy, 116(12), 1101-1110.

[11] Pytlik, A. (2018). Tests on hydraulic props equipped with yield valves at dynamic load modelling a rock burst. Archives of Mining Sciences, 63(2), 477-489. 
[12] Polski Komitet Normalizacyjny (1998). Polska Norma:

Kotwie górnicze. Wymagania [Polish Standard: Rock bolts.

Requirements]. PN-G-15091:1998. Warszawa (in Polish).

[13] Polski Komitet Normalizacyjny (1999). Polska Norma: Kotwie górnicze. Badania [Polish Standard: Rock bolts. Testing]. PN-G15092:1999. Warszawa (in Polish).

[14] Polski Komitet Normalizacyjny (1997). Polska Norma: Górnicza obudowa indywidualna. Stojaki cierne. Wymagania i badania [Polish Standard: Single prop mine support. Friction props. Requirements and testing]. PN-G-15533:1997. Warszawa (in Polish). 